\title{
THE KNOWLEDGE AND USE OF THE BALANCED SCORECARD METHOD IN BUSINESSES IN THE SLOVAK REPUBLIC
}

\author{
L'ubica Lesáková, Katarína Dubcová, Petra Gundová
}

\section{Introduction}

One of the management tools that is gaining popularity in business practice is the Balanced Scorecard (BSC). The BSC was developed by Robert Kaplan and David Norton in 1992 as an alternative to traditional performance measurement approaches that focus solely on financial indicators and are based purely on a business's past performance. During the years the Balanced Scorecard has evolved from its early use as a simple performance measurement framework to a full strategic planning and management system. It can be defined as a strategic planning and management system that is used to align business activities to the vision and strategy of the businesses, to improve internal and external communications and to monitor organization performance against strategic goals. The BSC can be understood as a management system which is structured according to the logic of the management circle ("plan-do-check-act") (Kaplan \& Norton, 2010).

\section{Balanced Scorecard -A Strategic Management Tool}

The Balanced Scorecard is a management system (not only measurement system) that enables businesses to clarify their vision and strategy and translate them into action. It provides feedback around the internal processes and external outcomes in order to continuously improve strategic performance and results. When fully implemented, the Balanced Scorecard transforms strategic planning from an academic exercise into the (nerve) centre of an enterprise (Kaplan \& Norton, 2007).

The aim of the Balanced Scorecard is to direct, help manage and change in support of the longer-term strategy in order to manage performance. The scorecard reflects what the businesses and the strategies are all about. It acts as a catalyst for bringing the "change" element within the businesses. BSC creates a comprehensive framework which considers the following perspectives and tries to get answers to the following questions: 1 . Financial perspective (how do we look at shareholders?); 2. Customer perspective (how should we appear to our customers?); 3. Internal business processes perspective (what must we excel at?); 4. Learning and growth perspective (can we continue to improve and create value?).

This tool is considering not only the financial results, which are important, but also those factors which actually drive businesses towards future success. The Balanced Scorecard lays stress also on other areas which are required to "balance" the financial perspective in order to get a total view of the businesses performance and improve the same (Evans, 2002). The framework tries to bring a balance and link between the financial and non-financial indicators, tangible and intangible measures, internal and external aspects and leading and lagging indicators.

The main benefit of managing with a combination of financial and non-financial information is that the use of leading, nonfinancial indicators facilitates proactive control and the ability to take a preventive action (De Waal, 2013). A balanced set of key financial and non-financial (CSF) critical success factors and KPIs (key performance indicators) enables management to focus on the really important issues that drive business performance and to monitor the achievement of strategic goals more closely. Using non-financial information improves the analytical skills of managers because they can identify the root causes of financial performance. 
Lesáková (2004) states that the BSC method is not just a grouping of important indicators of performance evaluation. Its consistent application provides a modern way of management, because it helps to align the business activities with the business processes of creating the company's value.

Synek et al. (2011) look at the BSC as a method of strategic management whose role is to align the interests of management with the interests of employees and the strategic goals with the operational management. The authors support exploitability of this method for linking the strategy with the daily decision making process.

Armstrong (2007) compared the method to a waterfall. The author claims that the BSC method passes through the businesses as a waterfall to ensure the measurement of the activities that contribute to the achievement of the overall businesses strategy. The idea captures the essence of the current importance of the BSC method in the strategic management of the company.

There are several authors who deal with the BSC method in the strategic business management and the problems emerging through its implementation in business (De Waal, 2013; Evans, 2002; Gavurová, 2012; Horváth \& Partners, 2002; Kaplan \& Norton, 2007; Lang, 2007; Karabašová, 2010; Virtanen, 2009 and others).

Proper understanding and implementation of the Balanced Scorecard method brings a number of benefits to businesses that are presented in literature. The authors of the BSC (Kaplan \& Norton, 2007) see the major contribution of this method mainly in the implementation of the business's vision and strategy into its objectives and measurements. The method connects the vision and the strategy with the daily decision making process. The BSC method facilitates the communication and understanding of the strategy across the business and helps to align individual goals of the employees with the business's objectives. These arguments are presented by Kaplan and Norton (2007), who state that the measurements should be used in a way other than a classical tool for revising the behaviour and past performance. The authors argue that the measurements in the BSC should serve mainly as an aid in formulating the corporate strategy, communicating it and aligning individual, corporate and departmental initiatives towards the achievement of the common goal.

In the year 2002 Kaplan and Norton formulated the main benefits of the BSC method resulting from the cooperation of different stakeholders in the business. First, they state that the method provides a clear picture of the corporate strategy which is understandable for the employees. Due to that the strategy becomes part of the daily activities of the employees. As the second benefit they indicate that BSC helps companies to define strategic partnerships with target customers and to focus attention on customers. Third, unless the businesses have set a strategy which includes strong partnerships with suppliers, the BSC assists in their maintenance through the monitoring of the performance in the internal business processes perspective. And fourth, the authors state that for businesses it is usually important to maintain good relationships with the community where the business is located. Determination of good relations is reflected in the perspective of internal business processes.

Based on the article "How a Balanced Scorecard can help your organization" (Balanced Scorecard Institute, 2012), we can conclude that the BSC can help businesses particularly in the following areas:

- to increase focus on strategy and results,

- to break communication noises between departments,

- to increase understanding of customer needs and flexibility to respond to them,

- to improve businesses performance by measuring the important areas,

- to assist the management in making better decisions based on analysis of relevant performance indicators,

- to assist the management with more effective planning of time and resources,

- to assist the management and employees to concentrate on important tasks.

Gavurová (2011) points out that the main benefits of the method lie mainly in helping to implement the strategy into everyday practice, then in simplifying communication and creating a uniform communication platform, in assisting to measure and enhance the performance and in supporting the explanatory power of the traditional performance indicators. Horváthová (2012) adds another benefit of implementing the BSC method, specifically the benefit of 
increasing the loyalty of customers as well as employees who are a presumption for the growth of its value.

There are many benefits and challenges to the Balanced Scorecard. The primary benefit is that it helps businesses translate strategy into action. By defining and communicating performance metrics related to the overall strategy of the businesses, the Balanced Scorecard makes the strategy come alive (De Waal, 2013). It also enables employees at all levels of the businesses to focus on important business drivers. In the article entitled "The Balanced Scorecard" (Balanced Scorecard Institute, 2013) the key benefits of using a Balanced Scorecard include: better strategic planning, improved strategy communication and execution, better management information, improved performance reporting, better strategic alignment and better organisational alignment.

\section{Aim, Material and Methodology}

The aim of the paper is to present the results of primary research focused on finding the current state of the knowledge and use of the Balanced Scorecard method in businesses in the Slovak Republic. On the basis of the research results will be formulated presumptions to improve the state of utilizing the BSC method by Slovak businesses.

With regard to the aim, there were formulated the following six hypotheses:

$\mathrm{H} 1$ : We assume that more than $50 \%$ of Slovak businesses do not know the Balanced Scorecard method.

$\mathrm{H} 2$ : We assume that less than $50 \%$ of Slovak businesses utilize the Balanced Scorecard method as a strategic management tool.

H3: We assume that more than $50 \%$ of businesses applying the Balanced Scorecard method in the Slovak Republic are large businesses.

$\mathrm{H} 4$ : We assume that the Balanced Scorecard method is implemented in the Slovak Republic mainly by businesses with foreign capital participation.

H5: We assume that the main reason for low utilization of the Balanced Scorecard method in practice is its difficult construction.

H6: We assume that the main reason for implementing the Balanced Scorecard method is the enrichment of business performance evaluation by non-financial measures.
The research was realized in the period from September 2014 to December 2014. We used the method of questioning with a questionnaire to obtain data. We distributed the questionnaire in the electronic form to small, medium and large businesses operating in the territory of the Slovak Republic. For the distribution and collection of questionnaires was used the Google Docs. Questionnaire which consisted of closed, semi-closed and opened questions.

The sample of businesses was compiled by random selection. We received fully filled questionnaires from 290 respondents, from which 6 questionnaires were eliminated due to incompleteness of responses. The remaining 284 questionnaires were subject to statistical processing. We verified the representativeness of the research sample by using the criterion of territorial representation of businesses in research.

The research sample consisted mainly of businesses located in the region of Bratislava $(27.96 \%)$, which was caused by the highest concentration of businesses in the region of Bratislava. The second most numerous representation had businesses from the region of Banská Bystrica (12.90\%), then businesses from the region of Žilina (11.47\%), Košice (10.75\%), Trenčín (10.39\%), Prešov (10.04\%), Trnava $(9.32 \%)$ and Nitra $(7.17 \%)$.

We verified the representativeness of the research sample by a chi-square test. Based on the level of significance $\alpha=0.05$, the $p$-value accounted for 0.128 , which means that the research sample was representative with respect to the location of the business unit.

What concerns the distribution of businesses by size in the research sample, there were represented all kinds of businesses: small businesses $(73.45 \%)$, medium businesses $(20.00 \%)$ and large businesses $(6.55 \%)$.

Regarding the sector representation, the research sample consisted of service businesses $(67 ; 23.59 \%)$, manufacturing businesses $(41 ; 14.44 \%)$, commercial businesses (34; $11.97 \%)$, construction businesses (24; $8.45 \%$ ), public organizations and organizations of public administration (20; 7.04\%), banks and businesses providing financial services $(14 ; 4.93 \%)$ and others $(84 ; 29.58 \%)$.

The data obtained via the questionnaire research were processed by using the MS Excel program and SPSS statistical program. We provided the statistical testing of data 
on the level of significance of $5 \%(\alpha=0.05)$. The validity of the formulated hypotheses was evaluated by an exact binomial test (testing the validity of $\mathrm{H} 1, \mathrm{H} 2$ and $\mathrm{H} 5$ ) and the Spearman Coefficient (verifying the validity of hypotheses $\mathrm{H} 3$ and $\mathrm{H} 4$ ).

In order to achieve our main objective, we used also other research methods, namely the method of analysis, synthesis, induction, deduction, abstraction, generalization as well as statistical methods.

\section{Results and Discussion}

The results of the questionnaire research pointed to a low familiarity with and usage of the Balanced Scorecard method in Slovak businesses. We found out that only $13.73 \%$ (39) respondents know exactly what the Balanced Scorecard method is and have implemented the method, $9.15 \%$ (26) respondents know the method, but have not implemented it yet, $77.11 \%$ (219) respondents do not know the method or did not answer the question (see Tab. 1).

\section{Tab. 1: Knowledge of the Balanced Scorecard method by businesses in the SR}

\begin{tabular}{l|r|r}
\multicolumn{1}{c|}{ Knowledge of the Balanced Scorecard method } & \multicolumn{2}{c}{ Number of Responses } \\
\cline { 2 - 3 } & \multicolumn{1}{c|}{ Total } & Percentage \\
\hline $\begin{array}{l}\text { Yes, we know exactly what the BSC method is and we have } \\
\text { implemented the method in our business }\end{array}$ & 39 & 13.73 \\
\hline Yes, but we do not utilize the method & 26 & 9.15 \\
\hline We do not know it & 56 & 19.72 \\
\hline No, but we would like to learn more about the method & 77 & 27.11 \\
\hline No, we are even not interested in the method & 86 & 30.28 \\
\hline Total & 284 & 100.00 \\
\hline
\end{tabular}

Source: processed according to the results of questionnaire research

Most businesses responded that they did not know what the Balanced Scorecard method is and even they were not interested to learn about it $(30.28 \%$ respondents, i.e. 86 businesses). 77 businesses (27.11\%) did not know the method, but would like to learn more about it. These businesses were mostly small businesses.

Based on the research results, we verified the validity of $\mathrm{H} 1$, in which we assumed that more than $50 \%$ of Slovak businesses do not know the Balanced Scorecard method. We verified the validity of this hypothesis by a binomial test and found out that the $p$-value $(0.00)$ is lower than the level of significance $\alpha$ (0.05). This confirmed the presumption that in the Slovak Republic there is a low number of businesses that know the Balanced Scorecard method.

In respondents who expressed that they exactly know what the Balanced Scorecard method is, we wanted to know from what sources they learned about the method. The question was designed in a way that provided respondents more options to answer. Our respondents acquired the knowledge about the Balanced Scorecard method mainly from various forms of education (80.39\% respondents), then from previous practical and personal experience (11.76\% respondents) and from references from other businesses $(7.84 \%)$.

We wondered how many respondents implemented the Balanced Scorecard method in the business. We found out that from 284 respondents there are only 39 respondents $(13.73 \%)$ using the Balanced Scorecard method as a strategic management tool, out of which $23(58.97 \%)$ are businesses of large size (250 and more employees). In order to verify $\mathrm{H} 2$ we used a binomial exact test. On the basis of $p$-value $(0.012)$, which is lower than the level of significance a (0.05), we acknowledge the validity of $\mathrm{H} 2$, which says that the Balanced Scorecard method is utilized as a strategic management tool by less than $50 \%$ of Slovak businesses.

H3 was verified through the Spearman coefficient. We assumed that there exists 
a dependence among the studied features (i.e. the size of business and utilization of the Balanced Scorecard method). Based on the results of the Spearman coefficient verified on the level of significance a (0.05), we can conclude that there exists a direct medium dependence $(r=0.514)$ among the studied features. This supports the fact that the implementation of the Balanced Scorecard method is proportionally dependent on the size of business. This means that the larger a business is, the higher the probability of implementing the Balanced Scorecard method in it is.

$\mathrm{H} 4$ was verified through the Spearman Coefficient as well. The sample was created from the respondents who have implemented the Balanced Scorecard method: 19 of them $(48.72 \%)$ were businesses with exclusively Slovak ownership, in 8 of them $(20.51 \%)$ a majority of ownership was Slovak, in 5 businesses $(12.82 \%)$ there was $50 \%$ of foreign ownership, in 5 businesses $(12.82 \%)$ a majority of stake was owned by a foreign owner and 2 businesses (5.13\%) were fully owned by a foreign owner. With this hypothesis we examined the dependence between business ownership and implementation of the Balanced Scorecard method. Based on the results of the Spearman Coefficient, the level of p-value (0.634) is higher that the level of significance $\alpha(0.05)$, which means that implementing the Balanced Scorecard method does not depend on the proportion of domestic and foreign owners of a business.

The evaluated hypotheses related to the size of businesses and structure of owners. A separate group of businesses is represented businesses that know the method, but do not implement it. This group comprises 7 businesses considering the implementation of the Balanced Scorecard method in the near future, 2 businesses having past experience with implementing the method and 18 businesses knowing the method but not having interest to implement it.

The reasons of businesses for lack of interest to implement the method were examined within $\mathrm{H} 5$ and they are presented in Tab. 2 below.

Among the most common reasons for disinterest in implementing the Balanced Scorecard method are lack of familiarity with the method, use of other strategic management tools, not performing strategic management (strategic planning) and other reasons like the size of business (applies mostly to small businesses), scope of business (industry in which a business operates, pointless use of new methods and ways of managing the business; some businesses stated that they utilize BSC mostly as a performance measurement tool.

We examined the difference between the frequencies of two main reasons concerning the disinterest in implementing the BSC method by the means of SPSS program. To evaluate the significance of difference we used a binomial test which confirmed that there is no significant

\section{Tab. 2: Reasons of disinterest to implement the BSC method by Slovak businesses}

\begin{tabular}{|c|c|c|}
\hline \multirow{2}{*}{ Reasons for disinterest in implementing the BSC method } & \multicolumn{2}{|c|}{ Number of Responses } \\
\hline & Total & Percentage \\
\hline The business applies intuitive management & 3 & 4.62 \\
\hline The business uses other tool/tools & 11 & 16.92 \\
\hline Lack of financial means & 0 & 0.00 \\
\hline Difficulty with the construction of BSC & 2 & 3.08 \\
\hline Lack of time & 4 & 6.15 \\
\hline Lack of familiarity with the method & 15 & 23.08 \\
\hline $\begin{array}{l}\text { We do not perform strategic management, we manage a business } \\
\text { according to the current situation on the market }\end{array}$ & 9 & 13.85 \\
\hline Other & 21 & 32.31 \\
\hline Total & 65 & 100.00 \\
\hline
\end{tabular}




\section{Fig. 1: Reasons for implementing the Balanced Scorecard in a business}

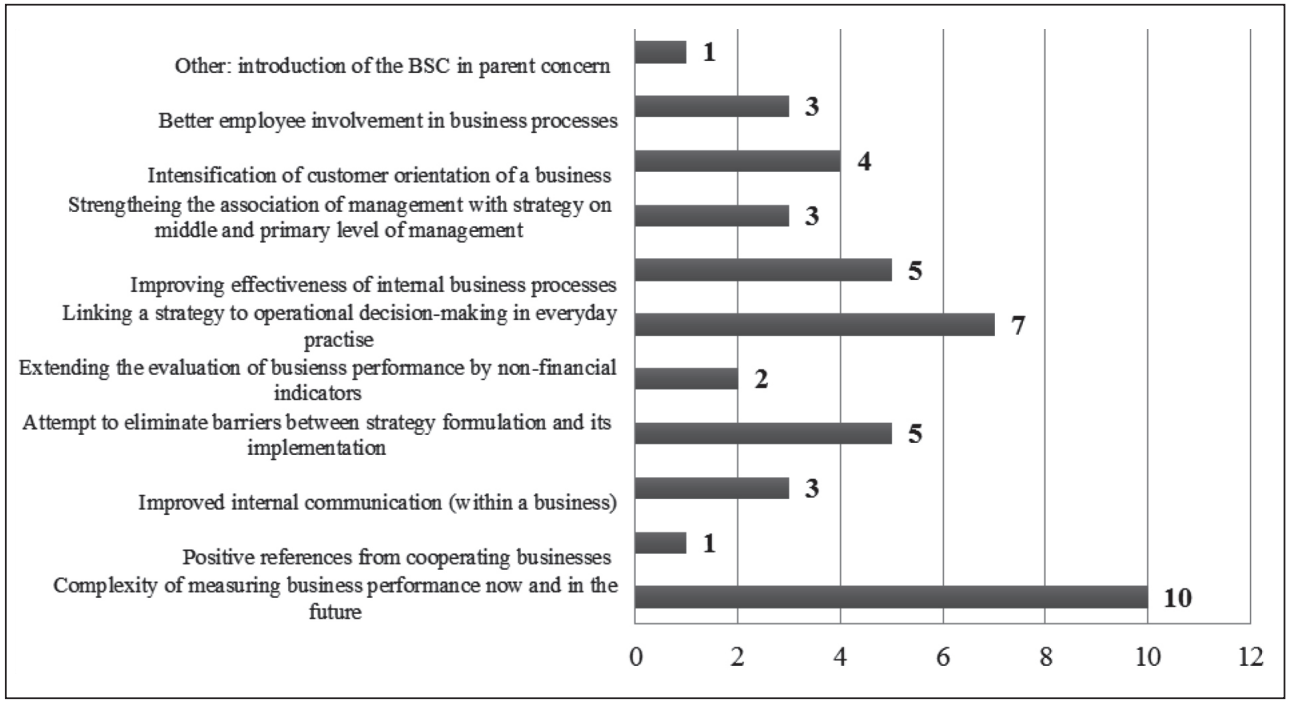

Source: processed according to the results of questionnaire research

difference between these two reasons (the level of significance $\alpha=0.05$ is lower than the $\mathrm{p}$-value $=0.405$ ). The most frequent reason why businesses decide not to implement the Balanced Scorecard method is lack of familiarity with the method; however, there are also other reasons. This means that it is not possible to accept $\mathrm{H} 5$.

On the other hand, the most frequent reason to implement the BSC method (with businesses that know the method) was the complexity of measuring business performance (10 respondents, i.e. $20.73 \%$ of answers). The reasons for implementing the BSC method are presented in Fig. 1.

Among the most frequently introduced reasons for implementing the Balanced Scorecard method is linking the strategy to operational decision making in everyday practice (7 respondents; $14.51 \%$ ), improving the effectiveness of internal business processes (5 respondents; $10.36 \%$ ), attempting to eliminate barriers between the strategy formulation and its implementation (5 respondents; $10.36 \%$ ) and intensifying customer orientation of the business (4 respondents; $8.29 \%$ ) and other (13 respondents; 26.95\%). One of the other reasons for implementation of the BSC was that the method was implemented in the parent concern. Based on the research results, the presumption formulated in $\mathrm{H} 6$ was not confirmed.

A separate part of empirical research was aimed at identifying the main benefits and main problems associated with the implementation of the BSC in Slovak businesses.

The businesses had a choice of more options (maximum was limited to 3 options) to answer the question on the main benefits of implementing the BSC method.

The results of the research showed that the main benefits of implementing the BSC method in businesses in the Slovak Republic were improved performance measurement and evaluation of business processes $(30.00 \%)$, support of strategic objectives through operational and short-term objectives $(20.00 \%)$ and introduction of periodical evaluation of strategic objectives (16.67\%).

Another question was focused on recognizing the most problematic phases of implementing the BSC method (Tab. 4).

The most problematic phases of implementing the BSC method the respondents mentioned were the integration of the method into existing management system $(25.00 \%$ of 


\section{Tab. 3: Benefits of implementing the BSC method from the viewpoint of Slovak businesses}

\begin{tabular}{l|c}
\multicolumn{1}{c|}{ Benefits of the method } & $\%$ of answers \\
\hline Improving performance measurement and evaluation of business processes & 30.00 \\
\hline Supporting strategic objectives through operational and short-term objectives & 20.00 \\
\hline Introducing an effective system of periodical evaluation of strategic objectives & 17.70 \\
\hline Improving the knowledge of customer needs and overall knowledge of the market & 16.15 \\
\hline $\begin{array}{l}\text { Increasing employee's motivation towards achieving personal performance } \\
\text { contributing to fulfilling strategic objectives }\end{array}$ & 16.15 \\
\hline
\end{tabular}

Source: processed according to the results of questionnaire research

\begin{tabular}{|c|c|c|}
\hline \multirow[t]{2}{*}{ Tab. 4: } & \multicolumn{2}{|c|}{$\begin{array}{l}\text { Problematic phases of implementing the BSC method from the viewpoint } \\
\text { of Slovak businesses }\end{array}$} \\
\hline & Problematic phases of implementing the BSC & $\%$ of answers \\
\hline \multicolumn{2}{|c|}{$\begin{array}{l}\text { Linking the strategic objectives to the objectives of departments, teams and } \\
\text { individuals }\end{array}$} & 8.33 \\
\hline \multicolumn{2}{|c|}{ Identification of critical success factors } & 8.33 \\
\hline \multicolumn{2}{|c|}{ Integration of the method into existing management system } & 25.00 \\
\hline \multicolumn{2}{|c|}{ Transformation of the departmental objectives into objectives of individuals } & 8.33 \\
\hline \multicolumn{2}{|c|}{$\begin{array}{l}\text { Linking the implementation of the method with the stimulation and motivation } \\
\text { of employees }\end{array}$} & 16.67 \\
\hline \multicolumn{2}{|c|}{ Selection of key performance indicators (measures) } & 16.67 \\
\hline \multicolumn{2}{|c|}{$\begin{array}{l}\text { Utilization of the results and information from the implemented method for corrective } \\
\text { and preventive actions in the business }\end{array}$} & 16.67 \\
\hline
\end{tabular}

Source: processed according to the results of questionnaire research

answers), identification of key performance indicators $(16.67 \%$ of answers) and linking the implementation of the method with the stimulation and motivation of employees (16.67\% of answers).

The research confirmed that the lack of interest to implement the BSC arises from the missing knowledge of the method. The information gained from the questionnaire survey points to a paradigm in managing Slovak businesses: an ingrained strong resistance to change is noticeable and managers are more inclined to known and verified methods.

\section{Conclusions}

The proper understanding and implementation of the Balanced Scorecard method brings a number of benefits to businesses. The method serves as a support for implementing the business strategy, it strengthens cooperation between business units, business departments, human resources of the business and serves as a communication tool in the business. Another important benefit is orientation of managers on key customers and partners and improvement of relations with the business stakeholders. The method makes business more transparent; it offers more relevant and complex information about the business that is helpful in early detection of possible bad direction of the business in future. If the method is properly implemented, it provides managers with feedback, offers them a space for self-reflection and leads to an improvement of internal processes by the means of communicating strategic objectives through all business levels.

The results of our research carried out on a sample of 284 businesses confirmed the presumption that the Balance Scorecard method is not only little used, but also the knowledge 
about it is very low in Slovak businesses. The low interest of businesses to implement the method into practice can be viewed critically. The most common reasons for disinterest in implementing the BSC are lack of familiarity with the method, use of other strategic management tools, performing the BSC only as a performance management tool as well as not performing the strategic business management. The research results confirmed that the larger the business is, the higher the probability of implementing the BSC is. The benefits of the Balanced Scorecard method correspond to the most frequent reasons for its implementation in businesses in the Slovak Republic, which are the complexity of measuring business performance at present and in future, linking the strategy to operational decision-making in everyday practice, improving the effectiveness of internal business processes, attempting to eliminate barriers between the strategy formulation and its implementation and intensification of customer orientation. Conversely, one of the most frequently cited reasons for low interest in implementing the method is lack of familiarity with it.

On the basis of the presented benefits and the results of the questionnaire research, we consider the Balanced Scorecard method a strategic management tool that should be presented more to Slovak businesses. Better knowledge of the Balanced Scorecard method can lead to a wider use of the BSC in Slovak businesses and thus taking an advantage of the benefits that the BSC offers.

When formulating proposals to increase the level of knowledge of the Balanced Scorecard method in Slovak businesses we come out from the preferred methods of obtaining information in businesses. Managers acquire new knowledge mostly through school education (educational activities) or practical training. A number of businesses gain new knowledge also from the experience of other businesses (cooperating businesses, competition) and also from specialized journals and magazines. Innovation is nowadays a key factor for entrepreneurial activity (Šipikal, Pisár, \& Uramová, 2010). With regard to these ways of obtaining information in Slovak businesses, the most suitable way of providing information about the BSC method appears to be educational activities as well as in-company training. Likewise, businesses have a possibility to use the services of special consulting agencies.
The Balanced Scorecard method can be implemented in different ways. The business can decide to implement the method by itself (in-house), with the help of consulting agencies or another expert who is a specialist in the BSC method. Synek et al. (2011) argue that in the process of designing (construction) and implementation of the BSC method into the business, the whole team of specialists should work together.

Based on the theoretical knowledge and practical experience of Slovak and foreign businesses, it is clear that for the proper implementation of the BSC method, the commitment of the top management is essential. We consider full support and active participation of the senior management an important precondition for successful implementation of the BSC. Full support and active participation of the senior management is required due to competencies and authority needed.

Similarly, managers at lower levels also have to be identified with the implementation of the BSC method. An essential point here is that managers have clearly defined competencies. Employees cannot be left out either - they should also have basic information about the method. Appropriate awareness reduces resistance to change as it minimizes the fear of the new and unknown.

In general, businesses have to meet certain prerequisites for successful implementation of the BSC method into their business practice. Several authors deal with this kind of research and define the assumptions that businesses should meet before the actual implementation of the BSC method. According to Karabašová (2010), the main prerequisites for successful implementation of the Balanced Scorecard are as follows: full support and active participation of the senior management, adaptation of all activities of the business to match the new governance, the business has to clearly define the responsibilities for achieving the measurements of the BSC and to connect them with the evaluation and remuneration of employees; a key factor here is the communication of the new system and involvement of all employees in its implementation.

It is evident that the Balanced Scorecard method could help our businesses not only measure the performance, but also manage the 
strategies which have to be adopted so that the long-term goals are achieved. In other words, the application of this tool could help ensure the consistency of vision and action which is the first step towards the development of successful businesses.

\section{References}

Armstrong, M. (2007). Řízení lidských zdrojů. Praha: Grada Publishing.

Balanced Scorecard Institute. (2012). How a Balanced Scorecard can help your organization. North Carolina (USA): Balanced Scorecard Institute. Retrieved January 6, 2012, from http://www.balancedscorecard.org/ Portals/0/BalancedScorecardlnstitute-BSC.pdf.

Balanced Scorecard Institute. (2013). The Balanced Scorecard. Nairobi: Balanced Scorecard Institute. Retrieved March 4, 2013, from http://balancedscorecardinstitute.org/ node/57.

De Waal, A. (2013). Strategic Performance Management (2nd ed.). Houndmills, Basingstoke: Palgrave Macmillan.

Evans, M. H. (2002). Course 11: The Balanced Scorecard. Airlington: Matt H. Evans. Retrieved April 11, 2013, from http://www. exinfm.com/training/pdfiles/course11r.pdf.

Gavurová, B. (2011). Systém Balanced Scorecard v podnikovom riadení. Ekonomický časopis, 59(2), 163-177.

Gavurová, B. (2012). Aplikácia vybraných podporných nástrojov $v$ problematických fázach systému Balanced Scorecard. Košice: Technická univerzita v Košiciach.

Horváth \& Partners. (2002). Balanced Scorecard v praxi. Praha: Profess Consulting.

Horváthová, J. (2012). Skúsenosti $\mathrm{s}$ budovaním systému BSC $\mathrm{v}$ praxi. Finančný manažment, 6, 44-52.

Kaplan, R. S., \& Norton, D. P. (1992). The Balanced Scorecard - Measures that Drive Performance. Harvard Business Review, 70(1), 70-79.

Kaplan, R. S., \& Norton, D. P. (1996). The Balanced Scorecard - translating strategy into action. Harvard Business School Press.

Kaplan, R. S., \& Norton, D. P. (2002). Partnering and the Balanced Scorecard.
Boston: HBS Working Knowledge. Retrieved November 5, 2012, from http://hbswk.hbs.edu/ cgi-bin/print/3231.html.

Kaplan, R. S., \& Norton, D. P. (2007). Balanced Scorecard (strategický systém merania výkonnosti podniku). Praha: Management Press.

Karabašová, L'. (2010). Metodický postup pre aplikáciu Balanced Scorecard do organizácie. Košice: Dominanta. Retrieved November 17, 2012, from http://www. dominanta.sk/MetodikaBSC.pdf.

Lang, H. (2007). Management. Praha: C. H. Beck Publishing.

Lesáková, L'. (2004). Metódy hodnotenia výkonnosti malých a stredných podnikov. Banská Bystrica: Univerzita Mateja Bela.

Šipikal, M., Pisár, P., \& Uramová, M. (2010). Support of innovation at regional level. E\&M Economics and Management, 13(4), 74-85.

Synek, M. et al. (2011). Manažérská ekonomika. Praha: Grada Publishing.

Virtanen, T. (2009). Guidelines for Implementing Balanced Scorecard. Helsinki: QPR. Retrieved April 4, 2013, from http:// www.prototechnika.It/qpr/wp-content/ uploads/2012/07/QPR-Guidelines-forImplementing-Balanced-Scorecard.pdf.

prof. Ing. L'ubica Lesáková, PhD. Matej Bel University in Banská Bystrica

Faculty of Economics Department of Corporate Economics and Management lubica.lesakova@umb.sk

Ing. Katarína Dubcová, PhD. Matej Bel University in Banská Bystrica

Faculty of Economics Department of Corporate Economics and Management katarina.dubcova@centrum.sk

Ing. Petra Gundová, PhD. Matej Bel University in Banská Bystrica

Faculty of Economics Department of Corporate Economics and Management petra.gundova@umb.sk 


\title{
Abstract
}

\section{THE KNOWLEDGE AND USE OF THE BALANCED SCORECARD METHOD IN BUSINESSES INTHE SLOVAK REPUBLIC}

\author{
Lubica Lesáková, Katarína Dubcová, Petra Gundová
}

The Balanced Scorecard method (BSC) has emerged since the late 1990s (as proposed by Kaplan and Norton) as one of the most successful concepts in the field of strategic performance management. It has evolved from its early use as a simple performance measurement framework to a full strategic planning and management system. Balanced Scorecard is used by many successful businesses all around the world. Main aim of the paper is to present the results of primary research focused on detecting the current state of the knowledge and use of the Balanced Scorecard method in businesses in the Slovak Republic. In the first part of the paper is presented the essence of the BSC method, formulated are the main benefits connected with the Balanced Scorecard implementation into the strategic management of the businesses. These benefits are defined according to the content analysis of domestic and foreign literature. Following the goal of the article next part presents the results of the empirical research based on the questionnaire survey. Results are connected with the evaluation of the six hypothesis defined in regard of the established goal of the paper. Formulated will be presumptions to improve the state of utilizing the BSC method by Slovak businesses. For the fulfilment of settled objectives we have used several scientific methods of examination, namely the method of analysis, synthesis, induction, deduction, abstraction, generalisation as well as statistical methods.

Key Words: Balanced Scorecard, strategic management, knowledge and use of the Balanced Scorecard method, Slovak businesses.

JEL Classification: M21, L25.

DOI: 10.15240/tul/001/2017-4-004 